
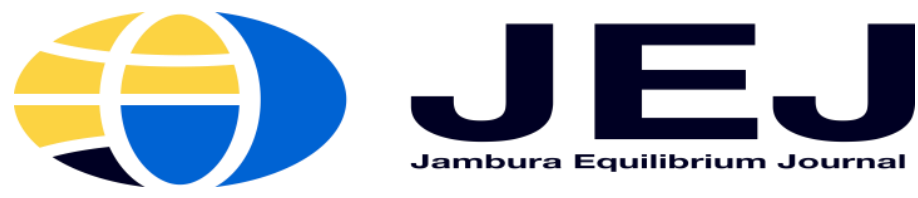

Volume 3. Issue 1. January 2021

P-ISSN 2655-9110

E-ISSN 2656-0445

http://ejurnal.ung.ac.id/index.php/equij

\title{
The Analyze of Investment For Alleviating Unemployment Problems in Banten Province
}

Sugeng Setyadi ${ }^{1}$, Oki Oktaviana ${ }^{2}$

Fakultas Ekonomi dan Bisnis, Universitas Sultan Ageng Tirtayasa, Banten, Indonesia ${ }^{1}$

Badan Perencanaan Pembangunan Daerah Provinsi Banten ${ }^{2}$

Abstract: The amount of investment coming into the Banten province has not been in line with the absorption of labor so that the percentage of the unemployment rate in this region always shows above the national average. Therefore, this study aims to analyze the investment in the Banten region in order to obtain a strategy that can alleviate unemployment problems. The research was conducted through a qualitative descriptive approach carried out from August to November 2019. In addition to being based on secondary data obtained from legitimate institutions, to strengthen the results of the analysis, focus group discussions were carried out involving related stakeholders. The results showed that in terms of the distribution of investment in each district/ city, proportion of investment that comes from FDI and DDI or even government spending is dominated by the North Banten and Central Banten regions. So far, the sectors that have become the priority of investors are electricity, gas and water, transportation, warehousing, and telecommunications, which have relatively few workers. Increasing investment in the agribusiness sector is an alternative for efforts to accelerate the reduction in the unemployment rate in Banten Province. Various agribusiness sub-systems ranging from upstream, on-farm agribusiness, downstream agribusiness and agribusiness service provider sub-systems will absorb a lot of labor if realized.

\section{Keywords: Unemployment; Investment; Qualitative Method}

\section{INTRODUCTION}

The process of development that is carried out is certainly not separated from the purpose of the state, as mandated in the constitution of the opening of the Law of Association of 1945 that embodies the welfare of the general, the intellectual life of the nation as well as a role as well in maintaining order world. One of the indicator used in measuring the success of the development is the achievement of the value of Human Development Index which consists of the dimensions of long and live healthy, dimensions of knowledge as well as the dimensions of decent live with per capita expenditure indicators to describe people's purchasing power [1]. One of the efforts to increase the people's purchasing power can be realized through the provision of jobs [2]. Economic growth and social welfare can be linked to an increase in job opportunities, because the creation of many job opportunities will increase economic growth and community welfare. Another opinion states that a rapidly developing economy is not a guarantee of a country's prosperity if it is not followed by an expansion of employment opportunities to accommodate new workers which are increasing every year [3].

Provision of employment opportunities cannot be separated from the entry of investment in the private sector and public spending in the government sector. Investment is one of the important factors determining the success of economic development because its existence is the basis for the realization of sustainable economic 
growth [4]. Investment is expenditure to buy capital goods and production equipment to increase the ability to produce goods and services available in the economy [5]. An increase in the amount of investment, both private and government investment, will affect the expansion of job opportunities in a region [6]. In general, higher investment implies a lower unemployment rate and conversely a decrease in investment results in increased unemployment. In addition to affecting the number of unemployed, investment also plays a role in increasing the rate of economic growth, in other words investment has a major contribution to economic development in a region. [7].

With new investments, new capital goods will be created so that they will absorb new production factors, namely creating new jobs or job opportunities. In addition, with an increase in investment, there will be additional output and new income in the production factor, which will increase national output which in the end will be an increase in economic growth. [8]

Based on the amount of incoming investment, Banten Province is always in the top ten ranking nationally. However, it seems that the inflow of investment into the Banten province has not been directly proportional to employment. This shows that the increase in employment due to an increase in investment value has not been proportional to the increase in the number of the workforce which continues to increase every year.

The discrepancy between investment and employment can be seen from several research results. The results of research conducted by Dimas and Woyanti found that investment has a negative relationship with employment in DKI Jakarta [9]. The same thing can also be seen from the results of research which states that direct investment has no significant effect on job opportunities in Malinau Regency [10].

The condition that the amount of investment is not in line with the reduction in the unemployment rate is probably due to the fact that incoming investment tends to be used in the capitalintensive processing industry sector with relatively little labor absorption or business owners who use their investment tend to purchase capital goods in the form of machines so that the absorption of labor be low [9].
The discrepancy between the increase in investment and the unemployment rate is also due to the performance of this sector in the economy over a certain period of time. The Central Statistics Agency of Banten Province stated that the increase in unemployment in Banten Province was generally influenced by the low performance of labor-intensive industries, especially the footwear industry in Tangerang Regency and Serang Regency as well as the textile and textile product industries in Tangerang Regency and Tangerang City which resulted in termination of employment [11]. The low performance of the industry was due to a reduction in shoe orders and a shift in production to West Java and a decline in textile demand from the Middle East.

Based on the problems previously mentioned, the distribution of investment allocations in the economic sector which provide more employment opportunities and the distribution of investment allocations in priority areas need to get more in-depth attention. For this reason, further analysis is needed related to efforts to increase investment value in line with reducing the unemployment rate in Banten province.

\section{METHODOLOGY}

This research was conducted using a qualitative descriptive approach based on data and information obtained during the study from August to November 2019. The aim to be achieved using this research method is to uncover facts, phenomena, and circumstances that occur based on research data and information. Qualitative descriptive research is to look for the holistic side or see the entirety of the data, facts and tell the data or information that is in accordance with the situation that is happening then analyzed based on appropriate scientific principles. The results of the analysis serve as the basis for preparing research recommendations.

The analysis was carried out based on secondary data obtained from agencies or institutions that have legitimacy as data producers such as the BPS-Statistics Indonesia, the Investment Coordinating Board, the Banten Province Investment Service and and the Banten Province Employment Agencies. To strengthen the 
results of the analysis, a series of focus Group Discussion (FGD) activities were carried out with participants from related stakeholders within the Banten provincial government, Regional Apparatus in the Regency/City who handle planning, investment or employment affairs, representatives of existing banking / capital institutions. in the province of Banten and Business Actors. In addition, the implementation of the FGD also presented resource persons from ministries / agencies in Central Government agencies to obtain a more holistic policies.

\section{RESULTS AND DISCUSSION}

The economic development of Foreign Direct Investment (FDI) and Domestic Direct Investment (DDI) which entered Banten Province shows that this region is still very attractive to investors with sectors that are very attractive to investors, namely[12]:

1) Electricity, gas and water;

2) Transportation, Warehousing and telecommunications;
3) Mining;

4) Food processing industry; and

5) Real estates, industrial estates and offices. Interestingly, Banten Province for the entry of investment can be seen from the data released by BKPM RI. In the BKPM RI report, it is stated that the realization of FDI and DDI investment that entered Banten province reached 56 trillions, which is the fourth largest among other provinces in Indonesia.[13]. Based on the location in the January - December 2018 period, DKI Jakarta had a DDI investment value of $49.1 \mathrm{~T}(14.9 \%)$, West Java 42.3 T, East Java 33.3 T (10.1\%), Central Java 27, 5 (8.4\%), and East Kalimantan 25.9\% (7.9\%), while West Java FDI Investment \$ 5.6 B (19.1\%), DKI Jakarta \$ 4.9 B (16.7\%), Banten \$ 2.8 B $(9.6 \%)$, Central Java $2.4(8.2 \%)$, and East Java \$ 1.3 B (8.2\%). In 2018, PMDN Banten was ranked sixth after DKI Jakarta, West Java, East Java, Central Java and East Kalimantan. As for PMA, Banten Province is in the third rank after West Java and DKI Jakarta.

Table 1. FDI and DDI Realization in Banten Province in 2016 - 2018

\begin{tabular}{llllc}
\hline & \multicolumn{2}{c}{ DDI } & \multicolumn{2}{c}{ FDI } \\
\cline { 2 - 5 } Year & \multicolumn{1}{c}{$\begin{array}{c}\text { Investation } \\
\text { (Billion Rupiah) }\end{array}$} & Project & $\begin{array}{c}\text { Investation (Million } \\
\text { USD) }\end{array}$ \\
\hline 2016 & 496 & $12.426,3$ & 2.161 & $2.912,1$ \\
2017 & 699 & $15.141,9$ & 2.479 & $3.047,5$ \\
2018 & 718 & $18.637,56$ & 1.895 & $2.827,3$ \\
\hline
\end{tabular}

\section{Source: BKPM RI}

The amount of FDI entering the province of Banten, although showing a fairly good performance, requires efforts of exentensification and intensification in the future. A more precise policy to strengthen the regional economy is still needed to increase investment attractiveness in Banten[14]. During the implementation of the Focus Group Discussion (FGD), key informant from the Investment Coordinating Board said:

"Efforts to expand and intensify investment must continue to be carried out by local governments, including Banten province. Intensification can be done by increasing the number of investments or types of investment that have entered the area so far, while the extension is carried out by finding investors for new investment potentials in the area concerned. Intensification is carried out through the creation of a conducive environment for business development. For extensification, the local government should improve coordination with BKPM considering that the authority of PMA is the authority of the central government "(source: Focused Group Discussion 24 October2019)

Based on the quotation from the FGD results above, it can be seen that the Banten provincial 
government still needs to increase its investment development efforts either through intensification or expansion. Associated with efforts to reduce the unemployment rate, extensification efforts were made by making more efforts for the entry of investors in the business sector which had not been the goal of investment so far. If all this time, the investment targets in Banten province have focused more on the electricity, gas and water, transportation, warehousing and telecommunication sectors, it is time for the Banten Province Investment and One Stop Integrated Services (DPMPTSP) to further promote investment potential in other sectors. which absorbs more labor. An agribusiness system based on the empowerment of the diversity of resources in each region, accommodating to the diversity of human resource quality and export-oriented is believed to be able to solve most of the existing economic problems.[15]. It is hoped that the construction of the Serang - Panimbang toll road will become a new attraction for investors to invest in the agribusiness / agro-industry sector in the Lebak and Pandeglang districts.

The hope that investment will enter the Pandeglang and Lebak areas along with the Serang - Panimbang toll road is also expected to narrow the difference in the amount of investment between the North, Central and South Banten regions. So far, investment flows into the Banten region are dominated by North Banten and Central Banten. According to data from the BPS of Banten Province, the amount of foreign investment that entered the northern part of Banten was $37.75 \%$ of the total FDI entering the province, and the largest percentage was $62.12 \%$ of the total FDI investment allocated in the Central Banten region. while for the South Banten region, the amount of incoming FDI is only $0.13 \%$ [16]. The small amount of foreign investment that entered the southern part of Banten was also the case with the domestic investment that entered this area. Based on data from BPS Banten Province, it is stated that the percentage of DDI entering the Southern Banten (Padeglang and Lebak) region only reached $2.97 \%$ of the total DDI entering the Banten region, while for North and Central Banten respectively 50.74\% and $46.29 \%$. The problem of the lack of investment going to Pandeglang and Lebak was also conveyed by one of the FGD participants who came from the Office of Investment Service of Pandeglang Regency as presented in the following quote:

"In accordance with its development vision, Pandeglang Regency wants to advance the economy through main activities in the fields of tourism, agribusiness and maritime business. Therefore the Pandeglang district hopes for assistance from the central government to bring investors to the Pandeglang area. (source: Focused Group Discussion 24 October2019)

The same thing was conveyed by FGD participants who came from Agency of Palnning Development Lebak Regency as presented below:

"The development vision of Lebak Regency is to make this area a leading tourism destination at the national level based on local resources. In fact, specifically in the regional performance indicators it is stated that at the end of the 2019-2024 RPJMD period the contribution of the tourism sector must reach $10 \%$ of the total GRDP. For this reason, Lebak Regency really hopes for the role of the Banten Provincial Government or the Central Government to help bring investors to this region to participate in building the world of tourism. The role of investors is highly expected considering that Lebak district has limited development budgets sourced from the APBD (source: Focused Group Discussion 24 October2019)

Based on the two quotations from the FGD results above, it can be seen that the governments of Pandeglang and Lebak Regency have limitations in financing development. This is confirmed from BPS data, the amount of capital expenditure in the district government budget in the South Banten region only reaches Rp. 0.78 trillions. This value is far from the total capital expenditure of local governments in the North Banten region which reached Rp. 3.9 trillions [16]. This condition is caused by the small amount of local revenue (PAD) due to the regional economic potential which has not been managed optimally. 
The problem of inequality in investment that enters Lebak and Pandeglang Regencies compared to other areas in Banten Province must be addressed by the Banten Provincial government by increasing the intensity of promotion of the potential of the business sector based on the resources it has. Therefore, apart from the aspect of increasing the quantity of incoming investment, selecting the appropriate investment sector must also be a consideration. Especially for FDI, the government through the Investment Coordinating Board (BKPM) can help promote and bring in investors as long as the regions provide comprehensive potential data and information.

\section{Description of Unemployment in Banten Province}

Economic development is an attempt to increase the standard of living of a nation which is measured by the level of real per capita income[17]. The economic development of a country can be seen from several economic indicators, one of which is the unemployment rate. Through the unemployment rate we can see the level of community welfare and the level of income distribution. Unemployment occurs as a result of the high rate of change in the workforce which is not balanced with labor absorption caused by low growth in job creation. The success or failure of an attempt to overcome this major problem will affect political stability in people's lives and continuity in long-term economic development. [18]. The Open Unemployment Rate (TPT) in Banten Province in August 2019 reached $8.11 \%$ and it's the highest value compared to other provinces in Indonesia and the only province with an unemployment rate percentage value above eight percent.[11].

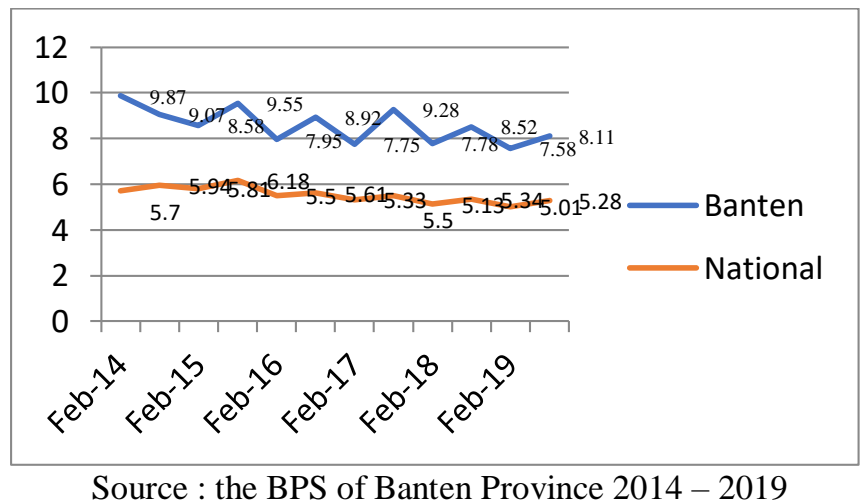

Figure 1. Unemployment Percentage of Banten and National Provinces 2014-2019

The picture above shows that unemployment in Banten Province until 2019 shows a decreasing trend. However, when compared with the national average unemployment rate, the unemployment rate in Banten Province is still at the highest. This shows that the amount of investment entering this area has not optimally provided employment opportunities for its residents.

Based on the Regency / City, the picture of the highest percentage of unemployment in the Banten province actually occurs in the Central part of Banten (Serang Regency, Cilegon City) and North Banten (Tangerang Regency) which previously mentioned dominating investment in
Banten, bothFDI and DDI.[16]. More complete is presented in the following table:

Based on the table above, it can be seen that Serang district is an area in Banten province with the highest TPT percentage level, namely $10.65 \%$. Although compared to the data for the same month in the previous year this percentage shows a decrease, this value is still far above the national average. In August 2018, the percentage of TPT in Serang district reached $12.77 \%$. In terms of numbers, Tangerang Regency has the highest number of unemployed people, reaching 164 thousand people. Based on these two things, it can be seen that the investment entering the Central Banten and North Banten regions as well as the 
large number of processing industry activities does not guarantee optimal employment.

Table 2. Amount and percentage of Unemployment in Regency/ Cities in Banten Province

\begin{tabular}{|l|c|c|c|c|}
\hline \multirow{2}{*}{ Regency / City } & \multicolumn{2}{|c|}{ Amount of Unemployment (Thousand) } & \multicolumn{2}{c|}{ Unemployment (Percent) } \\
\cline { 2 - 5 } & August 2018 & August 2019 & August 2018 & August 2019 \\
\hline Pandeglang & 44 & 45 & 8,33 & 8,71 \\
\hline Lebak & 47 & 47 & 7,69 & 8,05 \\
\hline Tangerang & 164 & 164 & 9,7 & 12,77 \\
\hline Serang & 84 & 73 & 7,4 & 7,13 \\
\hline Kota Tangerang & 78 & 79 & 9,33 & 9,68 \\
\hline Kota Cilegon & 19 & 19 & 8,16 & 8,08 \\
\hline Kota Serang & 24 & 25 & 4,67 & 4,79 \\
\hline $\begin{array}{l}\text { Kota Tangerang } \\
\text { Selatan }\end{array}$ & 37 & 39 & $\mathbf{8 , 5 2}$ & $\mathbf{8 , 1 1}$ \\
\hline Prov Banten & $\mathbf{4 9 7}$ & $\mathbf{4 9 1}$ & & \\
\hline
\end{tabular}

Source: the BPS of Banten Province2019

Another phenomenon that shows unemployment in Banten province is the higher unemployment rate in rural areas news in February 2019 stated that the percentage of TPT in rural areas reached than in urban areas. The official statistical

7.91 while in urban areas it was only $7.45 \%$.

Table 3. Percentage of Unemployment in Banten Province based on regional characteristics

\begin{tabular}{llll}
\hline & Feb & Feb & Feb \\
& 2017 & 2018 & 2019 \\
\hline $\begin{array}{l}\text { Urban } \\
\text { Area }\end{array}$ & 7,48 & 7,47 & 7,45 \\
$\begin{array}{l}\text { Rural } \\
\text { Area }\end{array}$ & 8,39 & 8,47 & 7,91 \\
\hline
\end{tabular}

Source: the BPS of Banten Province Februari 2019

Based on the table above, it can be seen that the percentage of TPT in rural areas always shows a higher value than in urban areas. This shows that economic activities in rural areas based on the primary sector (such as agriculture, fisheries, plantations, mining) have not been maximally absorbing labor. This condition is different from the conditions of employment in Indonesia in general which shows that the condition of unemployment in rural areas is always smaller than in urban areas.

The problem of higher unemployment in rural areas needs to be resolved immediately through comprehensive efforts involving various stakeholders. Looking at the 2019 BPS of Banten Province data, it can be seen that the number of people working in the agricultural sector (Agriculture, Plantation and fisheries) has decreased significantly. Compared to data for August 2018, in August 2019 there was a decrease in the number of people working in the agricultural sector by 150,900 people[11]. This is probably due to the relatively longer summer season in 2019 which has an impact on the inability to carry out activities in the agricultural sector. 
Table 4. Total Working Population by Main Employment (in thousands)

\begin{tabular}{|c|c|c|}
\hline Main Employment & August 2018 & August 2019 \\
\hline $\begin{array}{l}\text { Agriculture, Forestry and } \\
\text { Fisheries }\end{array}$ & 704,1 & 553,2 \\
\hline Mining and excavation & 25 & 25,7 \\
\hline Processing industry & $1.267,80$ & $1.340,00$ \\
\hline $\begin{array}{l}\text { Procurement of Electricity and } \\
\text { Gas }\end{array}$ & 19,5 & 27,9 \\
\hline $\begin{array}{l}\text { Pengadaan Air, Water Supply, } \\
\text { Waste Management, Waste and } \\
\text { Recycling }\end{array}$ & 52,5 & 39,6 \\
\hline Construction & 349 & 342,5 \\
\hline $\begin{array}{l}\text { Wholesale and Retail Trade; Car } \\
\text { and Motorcycle Repair and } \\
\text { Maintenance }\end{array}$ & $1.031,50$ & $1.163,00$ \\
\hline Transportation and Warehousing & 366,1 & 368,7 \\
\hline $\begin{array}{l}\text { Provision of Accommodation } \\
\text { and Food and Drink }\end{array}$ & 310,2 & 345,3 \\
\hline Information and Communication & 66 & 70,6 \\
\hline Financial Services and Insurance & 145 & 121,4 \\
\hline Real Estate & 49,4 & 56 \\
\hline Company Services & 155,6 & 138,2 \\
\hline $\begin{array}{l}\text { Mandatory Government } \\
\text { Administration, Defense and } \\
\text { Social Security }\end{array}$ & 139,8 & 177 \\
\hline Education Services & 233,5 & 298,9 \\
\hline $\begin{array}{l}\text { Health Services and Social } \\
\text { Activities }\end{array}$ & 82,8 & 69,7 \\
\hline Others & $\begin{array}{c}334,6 \\
\mathbf{5 . 3 3 2 , 5 0}\end{array}$ & $\begin{array}{c}425 \\
\mathbf{5 . 5 6 2 , 8 0}\end{array}$ \\
\hline
\end{tabular}

Table 5. Working Population Change by Main Employment (Percent)

\begin{tabular}{lcc}
\hline Main Employment & Change August 2018-2019 & Percent og Change \\
\hline Agriculture, Forestry & $-150,9$ & $-21,4$ \\
and Fisheries & 0,7 & 2,8 \\
Mining and excavation & 72,2 & 5,7 \\
Processing industry & 8,3 & 42,7 \\
Procurement of & & \\
$\begin{array}{l}\text { Electricity and Gas } \\
\text { Pengadaan Air, Water }\end{array}$ & $-12,9$ & $-24,5$ \\
$\begin{array}{l}\text { Supply, Waste } \\
\text { Management, Waste }\end{array}$ & & \\
and Recycling & $-6,5$ & $-1,9$ \\
Construction & & \\
\hline
\end{tabular}




\begin{tabular}{|c|c|c|}
\hline \multicolumn{3}{|l|}{ Wholesale and Retail } \\
\hline $\begin{array}{l}\text { Trade; Car and } \\
\text { Motorcycle Repair and } \\
\text { Maintenance }\end{array}$ & 131,6 & 12,8 \\
\hline $\begin{array}{l}\text { Transportation and } \\
\text { Warehousing }\end{array}$ & 2,6 & 0,7 \\
\hline $\begin{array}{l}\text { Provision of } \\
\text { Accommodation and } \\
\text { Food and Drink }\end{array}$ & 35,1 & 11,3 \\
\hline $\begin{array}{l}\text { Information and } \\
\text { Communication }\end{array}$ & 4,6 & 7 \\
\hline $\begin{array}{l}\text { Financial Services and } \\
\text { Insurance }\end{array}$ & $-23,6$ & $-16,3$ \\
\hline Real Estate & 6,6 & 13,3 \\
\hline Company Services & $-17,4$ & $-11,2$ \\
\hline $\begin{array}{l}\text { Mandatory } \\
\text { Government }\end{array}$ & & \\
\hline $\begin{array}{l}\text { Administration, } \\
\text { Defense and Social } \\
\text { Security }\end{array}$ & 37,2 & 26,6 \\
\hline Education Services & 65,4 & 28 \\
\hline $\begin{array}{l}\text { Health Services and } \\
\text { Social Activities }\end{array}$ & $-13,1$ & $-15,8$ \\
\hline Others & 90,4 & 27 \\
\hline Amount & 230,4 & 4,3 \\
\hline
\end{tabular}

Source: the BPS of Banten Province2019[11]

The depiction of the decline in workers in the agricultural sector due to the long summer season shows that the agricultural sector in the Banten province has not yet had the resistance to weather or climatic disturbances which should have been anticipated. In connection with government investment, in the future, stakeholders related to the development of the agricultural sector need to anticipate by allocating capital expenditures in the form of infrastructure development that can minimize disruptions to water supply for agricultural businesses such as construction of reservoirs, improvement of irrigation channels or procurement of pumping for farmer groups.

Overcoming the problem of unemployment in the Banten province can also be done by comparing the unemployment data that occurs in other regions. Looking at the data released by the Indonesia Statistics (BPS) in the Java Island region regarding unemployment data, it can be seen that the percentage of TPT has a positive correlation with the percentage of full-time workers (those who work more than 35 hours a week). This is shown in the image below:

Table 6. Percentage of Full Workers and Unemployment in Java Island Province

\begin{tabular}{|l|c|r|}
\hline Province & $\begin{array}{c}\text { \%Full } \\
\text { Worker }\end{array}$ & $\begin{array}{c}\text { Percentage of } \\
\text { Unemployment }\end{array}$ \\
\hline Jawa Barat & 78,02 & 7,99 \\
\hline Jawa Tengah & 73,32 & 4,49 \\
\hline Jogjakarta & 69,37 & 3,14 \\
\hline
\end{tabular}




\begin{tabular}{|l|l|l|}
\hline Jawa timur & 69,83 & 3,92 \\
\hline Banten & 82,48 & 8,11 \\
\hline Indonesia & 71,12 & 5,28 \\
\hline
\end{tabular}

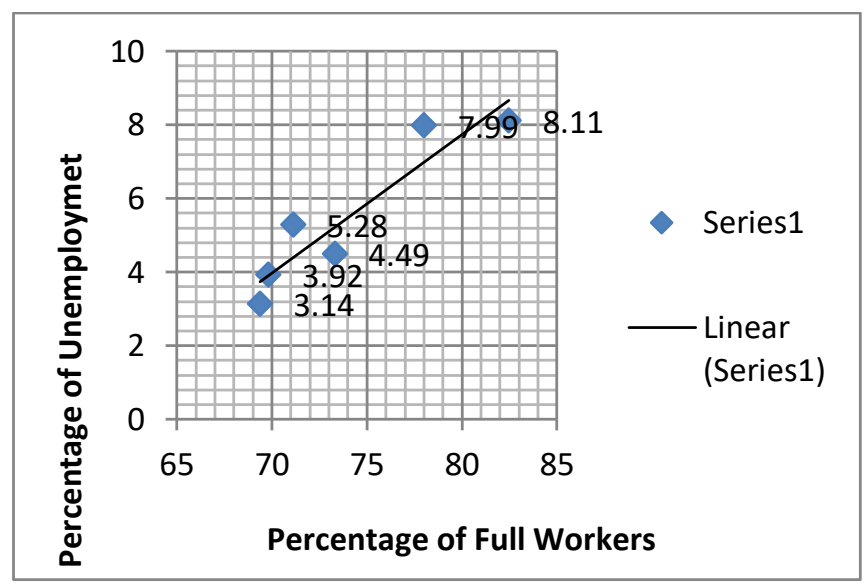

Figure 2. Relationship Between Unemployment and Full Workers

Based on the table above, it can be seen that the percentage of full-time workers in Banten is higher than other provinces in Java. The same thing happened in the percentage of the open unemployment rate. Therefore, it is necessary to increase the provision of employment or business in the informal sector through community economic empowerment.

\section{Identification of Investment Potential for Unemployment Alleviation}

Increased investment is one of the important factors in determining the level of income, investment activities allow a society to continuously increase economic activity and employment opportunities, increase national income and the level of prosperity [5] The existence of investment will encourage the creation of new capital goods so that it will absorb new production factors, namely creating new jobs or employment opportunities that will absorb labor which in turn will reduce unemployment.

Seeing the economic conditions in such a way, the increase in capital plays an important role in improving the economy, therefore the government seeks to improve the economy through collecting funds or investments from both the government and the private sector which are directed at economic activity, both Domestic Investment (PMDN) and Foreign Investment (PMA). This private sector investment can be in the form of private investment and domestic investment or foreign private investment. Therefore, local governments must issue policies in the form of programs and activities that can stimulate investment in the region.

The achievements of the provincial government in bringing in both PMA and PMDN investments are indeed quite good. However, on the other hand, high investment has not positively correlated with the reduction in the unemployment percentage. This is due to the fact that the majority of investment that enters the Banten province is more on the capital industry, which does not require large amounts of labor. For that we need alternative sectors that significantly provide employment opportunities.

One of the sectors that absorb a large number of workers is the agribusiness sector.

[19] stated that the agribusiness system includes four subsystems namely: 
1. Upstream agribusiness sub-system industries that produce capital goods for agriculture, such as the seed industry, crops, livestock, fish, agrochemical industries (fertilizers, pesticides, drugs, livestock vaccines. Agricultural machinery and equipment industry (agro-automotive);

2. Primary agricultural sub-system (onfarm agribusiness), namely cultivation activities that produce primary agricultural commodities (food crop farming, horticulture farming, medicinal plant farming (biopharmaca), plantation business, livestock business, fishery business, and forestry business)

3. Downstream agribusiness sub-system (down-stream agribusiness), namely industries that process primary agricultural commodities into processed products such as the food / beverage industry, the feed industry, the natural fiber goods industry, the pharmaceutical industry, the bio-energy industry, etc .; and

4. Agribusiness service provider subsystems (services for agribusiness) such as credit, transportation and warehousing, R\&D, HR education, and economic policy.

In Indonesia, investment opportunities in the agricultural sector are still quite large. This is motivated by several considerations, namely [20]:

1. Availability of natural resources (land, water and climate) and human resources are still large. Natural resource-based investment has a very strong foothold as it is supported by locally available raw materials. Such investment will not be easy to move to other countries because it is not a footloose type of investment.

2. Domestic demand for agricultural products will continue to increase due to the increase in population which is already large in number and the higher income of the people. World demand for Indonesian agricultural production will also continue to increase because this country is the main producer of several agricultural commodities needed by the world, especially palm oil, rubber, cocoa, coffee, pepper, nutmeg, vanilla and cinnamon.

3. The recent increase in world food prices provides greater opportunities for business actors to obtain higher and more sustainable profits.

4. The Indonesian government is committed to creating a conducive investment climate through various policies and regulations.

Based on the explanation above and the potential possessed by several regions in the province of Banten, especially Pandeglang and Lebak, it seems that the development of agribusiness sector business is quite an opportunity. This is reinforced by the plan for the existence of the Serang Panimbang toll road which will facilitate the flow of goods distribution as well as the regional development vision and mission in the two regions which specifically focuses on the development of the agricultural sector. The potential of the agricultural, plantation, fishery sectors owned by Pandeglang and Lebak districts should be more publicized so that they can attract investors to invest their capital. The seriousness of the Regional Government also needs to be realized in supporting the development of infrastructure to support production, such as irrigation that supports agricultural cultivation or fishing ports. With the availability of supporting infrastructure for production, it will be a consideration for investors because they do not need to spend a lot of money to start a business.

\section{CONCLUSION}

1. Its strategic location, infrastructure support and regional conduciveness have made Banten one of the national 
investment destinations. Therefore, in recent years, investment realization that has entered this region has always been in the top five, especially in foreign investment (PMA).

2. In terms of the distribution of investment for each regency / municipality in the province of Banten, there is a considerable gap. The proportion of investment that comes from PMA and PMDN or even government spending is dominated by North Banten and Central Banten.

3. The amount of investment entering the Banten province has not been in line with the high absorption of labor so that the percentage of the Open Unemployment Rate (TPT) in this region in the last few years has always shown a figure above the national average.

4. Among the various factors that affect the inflow of investment into an area, the employment factor, in this case the high district / city Minimum Wage, is the dominant factor that becomes the consideration of investors in investing in Banten.

5. Increased investment in the agribusiness sector is an alternative for efforts to accelerate the reduction of high unemployment in Banten Province. Various agribusiness subsystems ranging from upstream, onfarm agribusiness, down-stream agribusiness and agribusiness service sub-systems if realized will absorb a lot of labor.

\section{RECOMMENDATION}

1. The Banten provincial government needs to anticipate the investment distribution gap in each of the City districts. The low investment entering the South Banten region requires more massive promotional efforts related to the potential superior resources possessed by the region including South Banten.

2. To attract investment in the agribusiness sector, local governments need to pay more attention to the growth and development of this sector. More attention is in the form of construction of production support facilities and infrastructure, tax incentives and regional levies for agribusiness entrepreneurs, and preparation of human resources needed by the agribusiness industry market.

\section{REFERENCES}

[1] Badan Pusat Statistik 2015 Indeks Pembangunan Manusia 2014 Metode Baru Badan Pus. Stat. 66 37-9

[2] Lukis Panjawa J and Soebagiyo D 2014 Efek Peningkatan Upah Minimum Terhadap Tingkat Pengangguran J. Ekon. dan Stud. Pembang. 15 48-54

[3] Setiawan D, Maulida Y and Sandika R S 2014 Pengaruh Investasi Terhadap Penyerapan Tenaga Kerja Di Kabupaten Pelalawan J. Online Mhs. Fak. Ekon. Univ. Riau 1 1-16

[4] Komadin, Hartoyo S and Hakim D B 2013 Strategi Peningkatan Investasi Kabupaten Indramayu J. Manaj. Pembang. Drh. 5 1-14

[5] Sukirno S 2012 Makro Ekonomi: Teori Pengantar (Jakarta: Rajawali Press)

[6] Fahme N F 2013 Investasi Swasta dan Investasi Pemerintah Pengaruhnya terhadap Kesempatan Kerja di Sulawesi Utara J. EMBA 1 849-57

[7] Galí J, López-Salido J D and Vallés J 2007 Understanding the effects of government spending on consumption J. Eur. Econ. Assoc. 5 227-70

[8] Sandika M 2014 Pengaruh Investasi Terhadap Penyerapan Tenaga Kerja di Kabupaten

[9] Dimas D and Woyanti N 2009 Penyerapan Tenaga Kerja di DKI Jakarta J. Bisnis dan Ekon. 1624257 
[10] Hellen, Mintarti S and Fitriadi 2017 Pengaruh investasi dan tenaga kerja serta pengeluaran pemerintah terhadap pertumbuhan ekonomi serta kesempatan kerja INOVASI 13 28-38

[11] Badan Pusat Statistik Provinsi Banten 2019 Keadaan Ketenagakerjaan Banten Agustus 2019 (Serang Banten)

[12] Banten B I P 2019 Laporan Perekonomian Provinsi Banten Periode Agustus 2019 (Serang Banten)

[13] BKPM RI 2019 Realisasi Penanaman Modal PMDN-PMA JanuariDesember 2018

[14] Halik A 2016 Strengthening Regional Economic Policy for Investment Attraction: Case in Banten Province J. Bina Praja 8 1-11

[15] Saragih B 2001 Pembangunan Sistem Agribisnis di indonesia dan Peranan Public Relation 1-12

[16] Badan Pusat Statistik Provinsi Banten 2018 Analisis Sosial Ekonomi Provinsi Banten 2017 (Serang Banten)

[17] Suparmoko 1992 Ekonomi Pembangunan (Yogyakarta: BPFE. UGM)

[18] Djojohadikusumo S 1994 Perkembangan Pemikiran Ekonomi : Dasar Teori Ekonomi Pertumbuhan dan Ekonomi Pembangunan (Jakarta: Pustaka LP3ES)

[19] Saragih B 2001 Suara dari Bogor membangun sistem agribisnis

[20] Utomo P H 2010 Kinerja, Prospek dan Kebijakan Investasi di Indonesia Anal. Kebijak. Pertan. 8 151-65 